\title{
МІЖДИСЦИПЛІНАРНА ІНТЕГРАЦІЯ ЯК КЛЮЧОВИЙ АТРИБУТ ПРОВЕДЕННЯ БІНАРНОГО ЗАНЯТТЯ
}

\author{
Ю. С. Старова, Л. М. Проценко
}

\section{Київський міський медичний коледж}

У статті запропоновано приклад проведення комплексного бінарного теоретичного заняття викладачами дисциплін «Медсестринство в анестезіології та реаніматології», «Медсестринство в хірургії» та «Основи охорони праці та охорона праці в галузі» для студентів, які навчаються за спеціальністю 223 «Медсестринство».

\section{INTERDISCIPLINARY INTEGRATION AS A KEY ATTRIBUTE OF BINARY LESSON}

\author{
Y. S. Starova, L. M. Protsenko \\ Kyiv Municipal Medical College
}

The article suggests an example of a complex binary theoretical class, provided by teachers of "Nursing in anesthesiology and intensive-care medicine", "Nursing in surgery" and "The foundations of occupational safety and Occupational safety in the field" for students who study in the speciality 223 "Nursing”.

Вступ. Авіценна сказав: «Головним скарбом життя $\epsilon$ здоров'я, і щоб його зберегти, треба багато знати».

Сучасна молодь значно відрізняється від старших поколінь завдяки розвитку комп'ютерних технологій. щоб зацікавити студентів матеріалом, який вивчають, потрібно активно використовувати інтерактивні форми та інноваційні методи навчання. Одним із таких методів у будь-якому навчальному закладі $\epsilon$ бінарне заняття - лекційне та практичне. Для глибокого та різнобічного розкриття теми можна запросити й більшу кількість фахівців, які ефективніше висвітлять окремі питання [1]. Бінарне заняття за своїм визначенням - це одна з форм інтеграції предметів та реалізації міжпредметних зв'язків. Такі заняття встановлюють міцні зв'язки між навчальними дисциплінами, сприяють більш широкому та якісному засвоєнню навчального матеріалу, формують у студентів єдину за змістом і структурою систему знань, яка забезпечує майбутнім фахівцям необхідну теоретичну та практичну підготовку [3].

Із міждисциплінарною інтеграцією тісно пов'язане поняття «компетенція», тому що компетентність фахівця складається із сукупності знань, вмінь, бездоганності виконання практичних навичок та особистісних

(с) Ю. С. Старова, Л. М. Проценко, 2019 якостей студента, які він власне синтезує та інтегрує в процесі навчання, адаптуючи набуті здібності до своєї майбутньої професійної діяльності. Сучасний спеціаліст повинен бути компетентним, що визначається необхідністю оцінювати ризики, приймати рішення, вирішувати проблеми, реагувати на зміни, які постійно виникають в його практичній діяльності [2].

У Київському міському медичному коледжі педагоги вдало проводять комплексні (бінарні) заняття яскравим прикладом цього слугує співпраця викладачів хірургічного і природничо-наукового циклів. Завдяки таким бінарним заняттям накопичується цінний досвід із використання міждисциплінарної інтеграції у молодих колег-викладачів.

Згідно з педагогічним тлумаченням, міждисциплінарна інтеграція - це об'єднання знань, переконань та практичних дій на всіх етапах підготовки спеціаліста, синтез усіх форм занять відносно кожної конкретної цілі освіти у вузі. Міждисциплінарна інтеграція - явище багатобічне, але має свою кінцеву мету - забезпечити цілісність навчального процесу. При викладанні будь-якої клінічної дисципліни можна нарахувати більше десяти звернень до інших предметів - анатомії, фармакології, психології, безпеки життєдіяльності, біології - ось частковий перелік дисциплін, знання яких 
необхідні для глибокого вивчення однієї теми. Саме через таку міжпредметну інтеграцію й формується становлення студента не тільки як фахівця, а головне, як особистості. Самовдосконалення та самореалізація стають головною метою при формуванні набору загальних та професійних компетенцій спеціаліста, щоб стати висококваліфікованим і конкурентоздатним [4].

Основна частина. 3 метою демонстрації міжпредметної інтеграції викладачами коледжу було проведено відкрите комплексне теоретичне заняття на тему: «Термінальні стани. Серцево-легенева церебральна реанімація та правила безпеки в лікувально-профілактичних закладах при наданні екстреної медичної допомоги».

Заняття проводили викладачі дисциплін «Медсестринство в анестезіології та реаніматології», «Медсестринство в хірургії» та «Основи охорони праці та охорона праці в галузі».

Обов'язковим початком будь-якого типу заняття (лекція, практика, семінар) $\epsilon$ акцентування науковопрактичного обґрунтування теми, визначення навчальних цілей та мотивацій для студента.

Методична мета комплексного заняття:

- продемонструвати сприйняття студентами теми через міжпредметну інтеграцію;

- використання технічних засобів навчання (ТЗН) у вигляді мультимедійної системи, діаграм, таблиць, рисунків, наукових фільмів для активації розумової діяльності студентів.

На основному етапі лекції подають навчальний матеріал за планом, узгодженим між викладачами, які будуть брати участь у структуруванні комплексного заняття.

Пропонуємо стислий зміст методичної розробки відкритого комплексного теоретичного заняття, яке було проведено в Київському міському медичному коледжі:

- Патогенетичні зміни у мозку при діагностуванні клінічної смерті та ознаки термінальних станів.

Слайди в презентації містили інформацію про: анатомічні структури мозку, які по-різному реагують на процес відмирання; клінічні відмінності при діагностуванні термінального стану; диференціація клінічної та біологічної смерті реаніматором із медичною чи без медичної освіти. Особливу увагу приділяли поняттю «метаболічний ацидоз», яке в подальшому буде згадуватись на інших лекційних заняттях із розділу «Реаніматологія», зокрема при роз'ясненні таких питань, як: шоки, коматозні стани, повішання, ниркова недостатність, отруєння. Таким чином, забезпечується встановлення внутрішньопредметних зв'язків при викладанні дисципліни «Медсестринство в анестезіології та реаніматології». Ін'єкційне введення натрію гідрокарбонату при виникненні метаболічного ацидозу та особливості його фармакодинаміки $\epsilon$ цікавим питанням на логічне мислення студента та активізацію його розумової діяльності.

- Сторонні тіла в дихальних шляхах та види асфіксії.

Дане питання висвітлював викладач хірургії з наведенням прикладів із власного клінічного досвіду. Пропонували переглянути плівки інструментальних методів обстеження пацієнтів із педіатричної та терапевтичної практик. Для більш інформаційної насиченості давали перелік (сучасна класифікація) видів асфіксії та методи їх негайного усунення підручними засобами чи прийомами.

- Етапи серцево-легенево-церебральної реанімації (СЛЦР), методики проведення штучної вентиляції легень (ШВЛ) та масажу серця.

У вигляді структурно-логічних схем на слайдах мультимедійної системи були представлені три етапи проведення медичним персоналом реанімаційних дій з оглядом головних медичних препаратів (фармакологічне забезпечення), які застосовують при даних маніпуляціях. Окрім яскравих змістовних рисунків із зображенням техніки виконання прийому Сафара, ШВЛ та масажу серця, викладач анестезіології та реаніматології на лекції демонстрував в дії такі ТЗН, як сучасний манекен для проведення оживлення людини, інструментарій та обладнання для виконання штучного дихання - повітроводи, ларингоскоп, мішок Амбу, лицьові маски, інтубаційні трубки. Акцентував увагу на алгоритмах виконання штучної вентиляції легень та непрямого масажу серця, пояснював основні помилки, які виникають при недотриманні певної послідовності дій реаніматора, а також можливі ранні та віддалені ускладнення процесу оживлення.

- Ризик інфікування медичних працівників під час надання невідкладної медичної допомоги.

До контактів, які пов'язані з ризиком інфікування на робочому місці, належать: ушкодження шкіри інструментом, який міг бути інфікований (укол голкою, поріз гострим інструментом, розбитим склом та ін.); контакт слизових оболонок або ушкодженої поверхні шкіри із тканинами, кров'ю та іншими біологічними рідинами; тривалий (кілька хвилин і більше) або значний за площею контакт неушкодженої шкіри з тканинами, кров'ю та іншими біологічними рідинами. 
Дотримання вимог охорони та безпеки праці при роботі з усіма пацієнтами у будь-якій ситуації, незалежно від їхнього діагнозу, знижує ризик інфікування. Роботодавець повинен забезпечити працівників засобами захисту та інформувати їх про правила безпеки, але відповідальність за використання захисних засобів і дотримання правил безпеки цілком лежить на самих працівниках. Оскільки неможливо виявити всіх людей, інфікованих збудниками, що передаються з кров'ю, в основу захисту медичних працівників покладено «принцип універсальної перестороги». Зосереджено увагу не на конкретному пацієнті як джерелі інфікування, а на біологічних рідинах будь-якого пацієнта - тим самим вирішується безліч етичних, деонтологічних і правових питань. «Принцип універсальної перестороги» - вперше це правило запровадив Центр контролю за хворобами (США, Атланта) у 1986 р. За його методиками розроблено стандарти поведінки медпрацівників стосовно пацієнтів у багатьох країнах, у тому числі в Україні.

- Небезпечний контакт із біологічним матеріалом.

У цьому випадку медпрацівникові потрібно забезпечити необхідну медичну допомогу, консультацію, наступне спостереження та інші види допомоги. Після проведення вустановленому порядку реєстрації аварії (журнал форма 108) постраждалому пропонують (за його згодою) пройти обстеження на наявність антитіл до ВІЛ. Обстеження постраждалого медпрацівника необхідно проводити тільки після отримання інформованої згоди (потрібно заповнити бланк інформованої згоди на проведення постконтактної профілактики ВІЛ-інфекції). Постконтактна профілактика (ПКП) - це короткостроковий курс антиретровірусних препаратів для зниження імовірності розвитку ВІЛ-інфекції після контакту з біологічними рідинами, пов'язаного з ризиком інфікування ВІЛ. Обстеження на ВІЛ (конфіденційне) повинно бути проведене відразу ж після контакту, поєднаного з ризиком інфікування ВІЛ, і через 1, 3 , 6 місяців після контакту, навіть якщо постраждалий медпрацівник відмовляється від ПКП.

Вперше кров для тестування за кодом 115 (медичний контакт) відбирають безпосередньо після аварії, але не пізніше 48-72 год після неї.

Позитивний результат свідчить про те, що працівник був інфікований ВІЛ раніше і аварія не $\epsilon$ причиною зараження.

Якщо результат негативний, то наступне тестування повинні проводити через 3, 6 місяців і далі через рік.
- Алгоритм дій медичного працівника у разі виникнення аварійної ситуації на робочому місці під час виконання професійних обов'язків:

1) виконати профілактичні заходи;

2) повідомити адміністрацію лікарні, керівника робіт;

3) зареєструвати аварію в журналі;

4) оформити акт аварії;

5) здійснити забір крові пацієнта для тестування на антитіла до ВІЛ за його добровільною згодою;

6) кров пацієнта з направленням установленого зразка доправити в центр СНІДу;

7) постраждалий працівник із направленням, актом аварії, паспортом повинен з'явитися перші 72 год до центру СНІДу для консультування (у вихідні та святкові дні до чергового лікаря приймального відділення центру СНІДу) [8].

- Впровадження в нашій державі європейської системи безпеки праці, яка ґрунтується на ризикорієнтованому підході та циклі постійного вдосконалення, спрямоване на запобігання виникненню надзвичайних ситуацій, пропаганду гігієни та безпеки праці, збереження здоров'я працівників, що дає можливість підвищувати рівень промислової безпеки та виробляти продукцію високої якості, надаючи якісні послуги споживачам.

OHSAS 18001 - це міжнародний стандарт, який орієнтований на створення системи управління безпекою та гігієною праці, як невід'ємної складової частини загальної системи управління підприємством. Стандарт використовують підприємства для створення системи менеджменту безпеки праці та охорони здоров'я працівників.

Національний стандарт ДСТУ OHSAS 18001:2010 «Системи управління гігієною та безпекою праці. Вимоги» повністю гармонізований із міжнародним стандартом і передбачає безпосереднюучасть працівників у формуванні превентивних заходів з охорони праці, а також вдосконаленні всієї системи менеджменту охороною праці на підприємстві [6].

Високий ступінь ефективності лікувального процесу та безпечні умови праці медичного персоналу невід'ємні від суворого дотримання гігієнічних вимог, які $\epsilon$ найважливішим складником раціональної схеми функціонування сучасних лікарень та безпеки й охорони праці медичного персоналу.

У ст. 14 Закону України «Про охорону праці» зазначено, що працівник зобов'язаний [7]: 
- дбати про особисту безпеку і здоров'я, а також про безпеку і здоров'я оточуючих людей в процесі виконання будь-яких робіт чи під час перебування на території підприємства;

- знати і виконувати вимоги нормативно-правових актів з охорони праці, правила поводження з машинами, механізмами, устаткуванням та іншими засобами виробництва, користуватися засобами колективного та індивідуального захисту;

- проходити у встановленому законодавством порядку попередні та періодичні медичні огляди.

Відповідно до вимог Закону України «Про охорону праці» на підприємствах існує багаторівневий контроль за станом безпеки на робочих місцях. Регулярні перевірки в медичних установах сприяють дотриманню вимог безпеки персоналом і зниженню ризику інфікування на робочому місці.

- Сучасні стандарти реанімації та оцінка іï ефективності.

Коротко розглядали інформацію за новим керівництвом Американської асоціації серця з серцеволегеневої реанімації, яка містить сучасні принципи порятунку постраждалих із зупинкою серця.

На лекції викладачі використовували наступні технічні засоби навчання, дидактичні матеріали та методичні прийоми:

1. Мультимедійна система - не тільки підвищує статус викладача, а й розширює можливості художнього, наочного супроводу заняття, посилює міждисциплінарні зв'язки, організовує інтерактивні форми контролю знань. Презентації бінарного заняття демонстрували сучасні стандарти та методи виконання реанімаційних мір при виникненні різних клінічних ситуацій та нещасних випадків, у тому числі при необхідності надати медичну допомогу великій кількості уражених у мирний та військовий час; способи і засоби захисту працівників від впливу шкідливих виробничих чинників; пропаганду здорового способу життя; новітні дослідження у сфері фармації щодо застосування препаратів при лікуванні постреанімаційної хвороби; класифікацію методів видалення стороннього тіла з верхніх дихальних шляхів залежно від типу асфіксії.

2. Структурно-логічні схеми - розвивають наочнообразне мислення, слугують ефективним засобом для підвищення якості знань. Цей методичний прийом в педагогічній практиці допомагає студенту виходити із стану одноманітного сприйняття отриманої інформа- ції шляхом аналізу смислових фрагментів. Засвоєння теми найкраще відбувається у порівнянні, зіставленні явищ та побудови структурно-логічних схем, полегшує систематизацію навчального матеріалу для розуміння студента. Наприклад, схематично можна сконструювати та відобразити такі питання, як техніка виконання штучної вентиляції легень та непрямого масажу серця, змістовність заходів на 1-2-3 етапах СЛЦР, диференціацію клінічної та біологічної смерті.

3. Рольові ігри - обов'язково передбачають власну активність учасників, певні відносини між особистостями. Рольова гра розвиває такі комунікативні навички, як рольове спілкування між викладачем та студентами, забезпечує емоційне «включення» в ситуацію. На нашому занятті викладачем «Основ охорони праці» одному із студентів було запропоновано вийти з аудиторії для переодягнення з подальшою демонстрацією комплекту протиепідемічного одноразового одягу. Завдяки створеній ситуації студенти матимуть уявлення про головні заходи власної безпеки під час проведення реанімації постраждалого.

4. У вигляді діаграм чи схематичних зображень на лекції пропонують роздатковий матеріал, що містить сучасну інформацію про нові нормативи у клінічній практиці, положення, нормативи та накази м03 України, статистичні дані або новітні технології для проведення реанімаційних заходів.

5. Фото пацієнтів та рентгенівські плівки з власного клінічного досвіду викладача - також вдалий технічний засіб навчання для якісного проведення заняття, який надовго запам'ятають.

Висновки. Міждисциплінарна інтеграція - незамінний атрибут сучасної освіти. Сьогодні викладачеві при підготовці спеціаліста до його майбутньої діяльності потрібно вміти комплексно застосовувати знання, синтезувати та аналізувати їх, трансформуючи методи викладання з однієї науки в іншу. У вищому навчальному закладі набуває актуальності таке соціальне завдання, що зумовлене спрямованістю інтегрування в науці із вдалим втіленням міждисциплінарних зв'язків. Особистісні компетенції студента та ступінь його загальної підготовленості до трудової діяльності формуються саме через засвоєння змісту освітніх програм, впливом викладацького складу як індивідуумів та, насамперед, процесом міждисциплінарної взаємодії. 


\section{СПИСОК ЛІТЕРАТУРИ}

1. Задирака Л. В. Особливості розвитку професійно важливих психологічних якостей майбутніх медсестер / Л. В. Задирака // Медсестринство. - 2016. - № 3. - С. 19-22.

2. Варава О. Б. Діагностика готовності викладачів щодо розвитку інформаційно-аналітичної компетентності майбутніх медсестер / О. Б. Варава // Медсестринство. 2018. - № 4. - С. 10-12.

3. Богдан В. Методичне обґрунтування бінарних занять / В. Богдан, А. Грисюк // Освіта. Технікуми, коледжі. - 2018. - № 3, 4 (46). - С. 26-28.

4. Деркач Т. Лекція-візуалізація як форма активізації пізнавальної діяльності студентів коледжу / Т. Деркач, О. Деркач // Освіта. Технікуми, коледжі. - 2016. № 3, 4 (41). - C. 59-63.
5. Глумчер Ф. С. Анестезіологія та інтенсивна терапія : підручник / Ф. С. Глумчер, Л. П. Чепкий, Л. В. Усенко. - К. : Медицина, 2019. - 360 с.

6. Системи управління гігієною та безпекою праці. Вимоги / ДСТУ - OHSAS 18001 : 2010. - К. : Мінекономрозвитку України, 2010. - 28 с.

7. Про охорону праці : Закон України від 14.10.1992 р. № 2694 - XII.

8. Костюк О. К. Захист медичних працівників: профілактика ВІЛ/СНІДУ на робочому місці : посібник / О. К. Костюк. - К., 2008. - 23 с.

Отримано 27.09.19 